\title{
A NEW LENS FOR EXAMINING RURAL CHANGE $^{1}$
}

\author{
David L. Brown², Mark Schucksmith ${ }^{3}$
}

Received 7 March 2016; Accepted 3 June 2016

\section{Introduction}

Change, not stability, is the normal situation facing rural communities today. Regardless of the particular focus - social, demographic, economic, political, environmental - rural places are changing and these changes systematically affect life chances of people living and working in rural areas for better and for worse. Accordingly, social science can examine the determinants and consequences of rural changes thereby producing evidence based information to support informed policy and practice to meet challenges of change and to take advantage of opportunities. In this article, we develop a lens for examining rural change in the contemporary world. ${ }^{4}$

\section{Narratives of Rural Change}

Rural areas are diverse so there is no grand narrative of rural change. Rural communities experience a wide variety of development trajectories, have highly variable social, economic, and natural assets, and have different historical legacies. Moreover, some rural places can be extremely active in shaping their own destinies, while others are relatively powerless. While all places have their own histories, a number of interrelated metanarratives can serve as an heuristic framework for examining rural change, and the competing power-infused ways in which rural change is represented (Copus and Hörnström 2011). These alternative explanations of rural change include: (a) an agri-centric narrative, (b) an urban-rural access narrative, (c) a competitive economy narrative, (d) a places left behind narrative, (e) an amenity-based economy narrative, and (f) a narrative of society-nature interrelationships. We briefly discuss each of these narratives and show how they produce a lens for examining rural community structure and change in contemporary society.

\section{Agri-centric Narrative:}

Not surprisingly, the agricultural sector is privileged in this account of rural change. It is exemplified by the EU (DG Agriculture) consultation on CAP reform (CEC 2010:p.5) which asserts that "agriculture remains an essential driver of the rural economy in much of the EU," and that "The vitality and potential of many rural areas remain closely linked to the presence of a competitive and dynamic farming sector..." Consequently, the EU2020 goal of balanced

\footnotetext{
1 This article is based on our introductory chapter for the Routledge International Handbook of Rural Studies. (Shucksmith and Brown 2016)

2 Professor David L. Brown, College of Agriculture and Life Sciences, Cornell University, Ithaca (NY); e-mail: dlb17@cornell.edu

${ }^{3}$ Professor Mark Schucksmith, Newcastle University Institute for Social Renewal, Clermont Tower, Newcastle upon Tyne; e-mail: mark.schucksmith@ncl.ac.uk

${ }^{4}$ This framework is proposed to examine rural change in the global North.
} 
territorial development can best be obtained, from DG Agriculture's (and the farming lobby's) perspective, through farm subsidies and agricultural diversification.

\section{Urban-Rural Access Narrative:}

In this narrative, more associated with DG Regional and with geographers, rural population and economic growth is associated with access to urban centres. This growth reflects two urbanization processes: urban expansion into the countryside and counter-urbanization. In contrast, remote rural areas are disadvantaged and are expected to experience cumulative decline. The implied remedy, in policy terms, is to promote rural areas' access to urban centres through investment in transport and broadband. This narrative is shaped by the concept of the rural-urban interface, and by various types of mobility which give this liminal space social and economic meaning (Lichter and Brown 2011). Urban-rural interface is a dynamic space, a space of intense demographic, social, economic and environmental interaction. It is produced by increased mobility of population, labour, capital, information, pollutants. In other words, the interface is a space that integrates urban and rural rather than dividing urban from rural. Accordingly, in this narrative, the rural-urban binary is artificial and should be discarded.

\section{Competitive Economy Narrative:}

This narrative examines rural wellbeing with respect to the embeddedness of particular places within larger contexts and multiscalar processes. In particular, the fortunes of a given locality may be affected by the manner in which global capital penetrates local economy and society. The emphasis is on global competitiveness in a world where localities are increasingly interconnected and interdependent. With respect to Europe, for example, the Lisbon Strategy sets out the EU's aspiration to become the most competitive and dynamic knowledge-based economy, capable of sustainable economic growth with more and better jobs and greater social cohesion, and Europe's rural areas are expected to contribute to, and benefit from, this strategy (Court of Auditors 2006). The remedy, from this perspective, is investment in a skilled workforce and promotion of smart specialisation and knowledge economies. The question is, does the penetration of global capital into rural areas lead to economic dynamism, or to increased dependency, peripherality and precarity? Which rural areas fare better than others?

\section{A Places Left Behind Narrative:}

Some places are trapped in a vicious cycle of persistent underdevelopment. In the US, for example, about $15 \%$ of all counties (301) have had a poverty rate of $20 \%$ or higher since 1960 (USDA 2013). In these instances, political upheavals, economic transformations or environmental degradation result in chronic out-migration of working age population. The people left behind are multiply disadvantaged and their institutional capacity diminished. The challenge for social scientists is to identify the characteristics and historical legacies that contribute to persistent poverty and disadvantage at the community level, and to determine how these deficits and historical legacies might be preempted or neutralized. Disagreement exists about whether such action should be the responsibility of the inhabitants or of the state, or how these responsibilities might be shared effectively.

\section{An Amenity-based Economy Narrative:}

Rural communities with attractive natural amenities can commodify their environment and become venues for recreation and tourism (McGranahan 1999). However, amenity-based development is a two edged sword. Communities that commodify their natural environment in the form of recreation and tourism have experienced superior economic and demographic performance in recent years, but amenity-based economies also tend to generate inequality, through their reliance on low-paid employees, and displacement, through inflated house prices. Hence, amenity development in rural areas while inducing population and economic growth may inadvertently produce economic winners and losers, increased inequality, and political contention that weakens community cohesion. 


\section{A Coupled Society-Natural Systems Narrative:}

Changes in rural society and economy affect and are effected by the natural environment. The interdependence between society and nature has increased, and the causal pathway works in both directions. As Louise Fortman (2014: p. 159) observed, human activities in rural areas "can come back and bite you via natural processes," as illustrated by, the adverse impact of fracking on water quality, for example. But, changes in natural processes such as sea level rise, increasingly erratic weather systems, more widespread and persistent drought can also "come back and bite society" through population and other kinds of displacements. This perspective (like the others) raises issues of power, agency and governance. Coupled human-natural systems approaches are often presented as the most appropriate way for examining, and responding to, these processes.

\section{Research Themes and Empirical Questions}

When rural change is viewed through these various narrative frames, certain themes emerge that shape and motivate future research. Among these themes, we identify four as particularly salient at this time, and we suggest a set of research questions that present themselves within these themes. These include: (a) increased mobility \& interdependence, (b) rising social and spatial inequality and exclusion, (c) how the great recession and subsequent fiscal crisis adversely affects rural people and communities, and (d) rural communities as potential sites of resistance to (or reproduction of) neoliberalism.

\section{Increased mobility \& interdependence:}

Many scholars have commented on the world's increasing interconnectedness as we enter the $21^{\text {st }}$ Century, and for rural places this increases their accessibility while at the same time exposing them further to regional, national and global forces. The proclaimed 'annihilation of distance' has far reaching implications for rural structure and change, both in terms of the changing nature of urban-rural interdependence and in terms of global-local relations.

Since spatial processes reflect social, economic, and society-nature interrelationships, these mobilities integrate rural and urban space and give it social, economic and natural environmental meaning. For example, research on the "migration-commuting nexus" (Brown et al 2015) shows that rural in-migrants often retain their urban workplace. Hence, while they become rural residents they also become longer distance commuters. ${ }^{5}$ These forms of rural-urban mobility serve to integrate rural and urban places, but they also have potentially adverse environmental and social consequences including automobile-based air pollution, and because of the time spent in transit, reduced time for civic engagement in either rural or urban communities. Another example of an urban rural mobility is rural disposal of urban garbage. While this may seem to be a noxious activity from the rural standpoint, rural landfills produce jobs and tax revenue, and can be good neighbours if proper engineering practices are followed to control runoff, odour and aesthetic externalities. A third example of increased rural-urban mobility and resulting interdependence is direct marketing of locally grown food in urban markets. This win-win situation provides a relatively unmediated market for produce grown on small to medium size farms while providing a supply of wholesome food to urban consumers.

The above examples focus on internal movements of people, labor, information, capital within nations, however, mobility between nations is also increasingly important with potentially huge humanitarian and political consequences. For example, while the focus has traditionally been on the impact of internal migration on rural communities, international migration is headed for new destinations, many of which are rural. Population displacement is likely to remain an important and continuing feature of the 21st Century because of the fragility of nation states, the rise of political and religious extremism, and because climate change is affecting the sustainability of communities, environments and economies. Social science research needs to examine the changing nature of migration and displacement occurring in rural places to gain a better

${ }^{5}$ Generally travelling alone in a private automobile. 
understanding of the implications of such mobility for migrants themselves and for the communities of origin and destination.

\section{Rising inequality and exclusion:}

The second theme reflects the very nature of uneven development in highly developed societies. Spatial inequality exists between urban and rural communities, and between neighborhoods within rural communities themselves. Within this overall theme, we recommend that social scientists examine the social and spatial processes that contribute to producing and reproducing uneven spatial development, and seek to establish the causal processes by which living and working in an underdeveloped place contributes to constrained mobility, diminished wellbeing, and social and economic insecurity. As indicated earlier, some rural areas have developed high levels of well-being and opportunity while others are mired in persistent poverty and underdevelopment. In a world where income and wealth are increasingly concentrated among the highest levels of society, living in poor places can be especially troubling. Moreover, for persons who are poor to begin with, living in an under-resourced community can be a "double whammy" that negatively affects personal mobility. This is especially true in today's neoliberal society where many previously public services have been commodified. A frequent result is that an increasing share of people have relatively little money, are responsible for purchasing and increasing share of services with that money, and often live in underdeveloped areas where services are seen as unprofitable and hence are not locally available (Mitnick et al 2015). This vicious cycle affects prospects for both personal and community development. Research needs to evaluate the relative effectiveness of alternative rural policy choices designed to interrupt cycles of persistent underdevelopment while at the same time promoting regional and national growth and development.

\section{The fiscal crisis of the state and precariousness:}

The great recession and the subsequent fiscal crisis of the state affects rural people's well-being and vulnerability, and the development prospects of rural communities and economies. Governments throughout the world have rolled back public expenditure and services as a result of the historic 2008 recession. However, many scholars feel that this roll back would have occurred regardless of the recession due to the growing ascendency of neoliberal ideology that is shaping state policies throughout the capitalist world. The weakening social contract in today's neoliberal world affects the social, economic, and environmental vulnerability of rural people and communities. The privatization of essential services such as health, education, waste removal, etc. is particularly difficult in rural areas where market provision of services may not be profitable. This, of course, is a critical aspect of social exclusion based on residence since rural residents have access to fewer and often poorer services or they must travel substantial distances to obtain them in larger markets where they are becoming increasingly concentrated (Warner 2003). Future social scientific research should examine the impacts of macroeconomic policies on rural people's well- being, and how the re-definition of social protection challenges social security and social exclusion in rural communities. One size fits all urban service models may systematically disadvantage rural people and communities. Evidence-based social science analysis can help to avoid such disadvantageous outcomes.

\section{Rural communities as sites of resistance to neoliberalism:}

As Centeno and Cohen (2012) observed, the Great Recession may have raised serious questions about the neoliberal regime, but it remains unchallenged and continues to shape social and economic policy in the post-recession era. As discussed above, rural people are thought to be disadvantaged during neoliberalism because of their relative lack of economic and demographic clout, and because market provided services in small, and often low income, rural markets are unprofitable. While this may be the case, rural (and urban) communities do not necessarily knuckle under to external market forces. Rather, some communities have sufficient resources and political agency to mobilize against neoliberal policies and promote local development. Rural social scientists have identified examples of resistance to neoliberalism such as economy-based land reform in Scotland and Norway (McKenzie 2013; Shucksmith and Rønningen 2011), and 
alternative food networks (Fairbairn 2012; Lewis et al 2013). These examples hold out promise that place-based communities can provide viable alternatives to neoliberal economy, in the form of what Peck and his colleagues (2010) have called a "progressively variegated economy." The defining trait of such sites of resistance is an effective combination of local resources (social, economic, political, and institutional), plus effective linkages with external institutions, organizations and power centres. The result is a community that can mobilize in its own interest to make things happen or to stop things from happening when such changes are seen as undermining local society, economy and autonomy. Examples of endogenous and neoendogenous development span from economic development, to locally appropriate service delivery schemes, to environmental governance ${ }^{6}$.

\section{A Problem -Focused Social Science Can Contribute to Enhanced Rural Well-Being}

The 21st century will bring rapid, transformational rural change; much of it in ways we have not foreseen, and to which people in rural areas (as elsewhere) will have to adapt as best they can, with or without the help of an enabling state (Shucksmith 2010). Rural studies can, and should, contribute to ameliorating these challenging issues. Rural social scientists must continue to provide research-based evidence to inform policy and practice. But, we must be critically reflexive, aware of the "field" and how it is infused with power (Bourdieu 1980).

Rural studies can hold up a mirror to society to foster public deliberation and debate about what we understand to be a 'good society' and a 'good life'. This requires working across boundaries: between academic disciplines, between universities and society, between research, teaching and engagement, and between nations. Affecting policy and practice may mean working with less privileged groups, but equally it requires speaking "truth to power," or challenging powerful interests. The alternative, retreating to the university, is unacceptable. Rural studies is an applied social science, and as such must engage with society in assertive and effective ways. We can, and should, make a difference.

\section{References}

[1] Bourdieu, P. (1980). The Logic of Practice. Stanford, Stanford University Press.

[2] Brown, D. L., Champion, T., Coombes, M. \& Wymer. C. (2015). The Migration-commuting nexus: migration and commuting in rural England, 2002-2006: A longitudinal analysis. Journal of Rural Studies. 31: 118-128. DOI: 10.1016/j.jrurstud.2015.06.005.

[3] CEC (2010). Europe 2020: A strategy for smart, sustainable and inclusive growth. COM (2010) 2020 final. Brussels: Commission on European Communities.

[4] Centeno, M. \& Cohen, J. (2012). The arc of neoliberalism. Annual Review of Sociology. 38: 317-340. DOI: 10.1146/annurev-soc-081309-150235.

[5] Copus, A. \& Hörnström, L., eds. (2012). The New Rural Europe: Towards a Rural Cohesion Policy. Stockholm: Nordregio.

[6] Court of Auditors (2006). Rural development investments: Do they effectively address the problems of rural areas? Retrieved from http://www.reformthecap.eu/blog/tag/RuralDevelopment.

[7] Fairbairn, M. (2012). Framing transformation: the counter-hegemonic potential of food sovereignty in the U.S. context. Agriculture and Human Values. 29(2), 217-230. DOI: $10.1007 / \mathrm{s} 10460-011-9334-\mathrm{x}$.

\footnotetext{
${ }^{6}$ Rural areas can also reproduce neoliberalism through conservative voting patterns and by being overly influenced by external power. Institutions such as higher education can aid and abet such neoliberal collaboration by being overly influenced by transnational agribusiness, for example. (Shucksmith and Brown 2016)
} 
[8] Fortman, L. (2014). Connections: The next decade of rural sociological research on natural resources and environment (pp. 159-171). In C. Bailey, L. Jensen \& E. Ransom, eds., Rural America in a Globalizing World. Morgantown: Univ. of West Virginia Press.

[9] Lewis, N., Le Heron, R., Campbell, H., Henry, M., Le Heron, E., Pawson, E., Perkins, H., Roche, M. \& Rosin, C. (2013). Assembling biological economies: region-shaping initiatives in making and retaining value, New Zealand Geographer, 69(3), 180-196. DOI: $10.1111 / \mathrm{nzg} .12031$.

[10] Lichter, D. \& Brown, D. L. (2011). Rural America in urban society: Changing spatial and social boundaries. Annual Review of Sociology. 37, 565-592. DOI: 10.1146/annurev-soc-081309150208.

[11] McGranahan, D. (1999). Natural amenities drive rural population change. Agricultural Economic Report 781. Washington, DC: USDA-ERS.

[12] Mackenzie, A. F. D. (2013). Places of Possibility: Property, Nature and Community Ownership. Chichester: Wiley-Blackwell.

[13] Mitnick, P., Cumberworth, E., \& Grusky, D. (2015). Social mobility in a high inequality regime. Annals of the American Academy of Political and Social Science 663(1), 140-184. DOI: $10.1177 / 0002716216637048$.

[14] Peck, J., Theodore, N. \& Brenner, N. (2010). Post neoliberalism and its malcontents. Antipode. 41(1): 94-116. DOI: 10.1111/j.1467-8330.2009.00718.x.

[15] Shucksmith, M. (2010). Dis-integrated Rural Development: neo-endogenous rural development, planning and place-shaping in diffused power contexts. Sociologia Ruralis, 50(1), 1-15. DOI: 10.1111/j.1467-9523.2009.00497.x.

[16] Shucksmith, M. \& Brown, D. L. (2016). Framing rural studies in the global north (pp. 1-26). In Shucksmith, N. \& Brown, D. L., eds., Routledge International Handbook of Rural Studies. New York: Routledge.

[17] Shucksmith, M. \&. Rønningen, K. (2011). The uplands after neoliberalism? The role of small farm in rural sustainability. Journal of Rural Studies, 27, 275-287. DOI: 10.1016/j.jrurstud.2011.03.003.

[18] USDA. 2013. Persistent poverty counties 1980-2011. Retrieved from: http://www.ers.usda.gov/topics/rural-economy-population/rural-poverty-wellbeing/geography-of-poverty.aspx.

[19] Warner, M. (2003). Competition, cooperation and local governance (pp. 252-262). In Brown, D. L. \& L. Swanson, eds., Challenges for Rural America in the Twenty-First Century. University Park: Penn State University Press. 